\title{
Det som er juridisk riktig, er ikke alltid etisk riktig
}

Praksis er mer komplisert enn lovverket. Derfor trenger vi også etikken for å utøve moralsk skjønn.

\section{Anne Kari Tolo Heggestad}

Professor

Fakultet for helsefag, VID vitenskapelige høgskole

Etikk Lovverk Moralsk skjønn

\section{Hovedbudskap}

Lovverket er nødvendig, men ikke nok hvis vi skal yte moralsk forsvarlig helsehjelp. Vi trenger i tillegg etiske retningslinjer og et faglig og moralsk skjønn som en veiledning når vi skal fortolke loven.

«Uden skøn nøje at gå efter lovens bogstav, efter en eller anden ordlyd, kan lige så godt ske i handlinger, der går stik imod lovens ånd. Mennesket må - i skønnet - gå op i handlingen, besjælet af lovens ånd» (1).

Dette sitatet fra den danske teologen og filosofen K.E. Løgstrup understreker nettopp at vi ikke bare kan følge lovens bokstav, men at vi også må ha med oss et moralsk skjønn for å kunne tolke loven.

\section{Loven og etikken henger sammen}


Som sykepleiere har vi flere ulike lovverk vi må forholde oss til. De to viktigste er pasient- og brukerrettighetsloven og lov om helsepersonell (2). Lovverket skal blant annet sikre at pasientene får kvalifisert behandling, og bidra til tillit og kvalitet i tjenestene.

Det er en nær sammenheng mellom lovverk og etikk, og når man står overfor etiske problemstillinger, kommer man ofte ikke utenom lovverket. Lovverket kan i mange sammenhenger ses på som en formalisering og kodifisering av en moral som over tid har blitt allment akseptert (3).

\section{«Flere av de etiske prinsippene er nå også lovfestet.»}

Det ser vi blant annet ved at flere av de etiske prinsippene nå også er lovfestet. Eksempler på dette er plikten vår til å ivareta pasientens autonomi og regulering av tvang i helsetjenesten.

Andre eksempler er hvordan ikke-skade-prinsippet og velgjørenhetsprinsippet ivaretas gjennom vår juridiske plikt til å utøve forsvarlig og omsorgsfull hjelp.

\section{Hvorfor trenger vi både jussen og etikken?}

Det kan derfor være naturlig å spørre seg om vi trenger både jussen og etikken. Er det ikke nok at vi holder oss til det lovverket sier? Jeg mener at det er flere grunner til at vi også trenger etikken. Her vil jeg gå inn på noen av disse grunnene.

\section{«Lovverket må fortolkes innenfor den praksisen der loven skal utøves.»}

En viktig grunn til at vi trenger etikken, er at lovverket må fortolkes innenfor den praksisen der loven skal utøves. I denne fortolkningen er vi avhengig av å bruke faglig og moralsk skjønn. Og det er i det moralske skjønnet at etikken kommer inn.

Når det for eksempel står i lovverket at vi har plikt til å utøve forsvarlig og omsorgsfull hjelp, må dette fortolkes i en kontekst. Hva som ligger i begrepene «forsvarlig» og «omsorgsfullt», er ikke gitt i lovverket, og forsvarlighetsbegrepet er et tøyelig begrep.

Mangel på ressurser kan for eksempel føre til at man tolker forsvarlighetsbegrepet som en minstestandard, under det som kan anses som optimal behandling til det beste for pasienten. Her kan etikken fungere som et korrektiv og hjelpe oss til å unngå å tøye strikken så langt at hjelpen vi gir, ikke lenger blir god og omsorgsfull (4). 


\section{Tvang utøves i gråsonen av loven}

En annen viktig grunn til at det ikke er nok å forholde seg til lovverket, er at lovverket ikke fanger kompleksiteten i tjenestene. Et eksempel på dette er knyttet til tvang i kapittel 4a i pasient- og brukerrettighetsloven (5).

Formålet med reglene er å yte nødvendig helsehjelp for å hindre vesentlig helseskade samt å forebygge og begrense bruk av tvang. I dag har vi ett lovverk som gjelder for somatisk helsetjeneste, og ett som gjelder for psykisk helsevern.

Samtidig vet vi at pasienter, for eksempel i sykehjem, både kan ha somatiske og psykiske lidelser. Vi vet også at det skjer tvang i gråsonen av den behandlingen kapittel 4a i pasient- og brukerrettighetsloven regulerer (6).

Et eksempel på tvang som er i gråsonen av kapittel 4a (6), er forordning av psykofarmaka til engstelige eller urolige pasienter på en somatisk sykehjemsavdeling. Noen vil hevde at dette kan regnes som tvang knyttet til psykisk helsehjelp, og derfor ikke kan finne sted på et sykehjem.

Andre igjen vil si at det å gi psykofarmaka ved tvang for å roe pasienten for så å kunne gi somatisk helsehjelp, kan forsvares i henhold til kapittel 4a.

Dette eksempelet viser hvor vanskelig det kan være å tolke loven i praksis. Det viser at praksis er mer komplisert enn lovverket, og at det kan være vanskelig å skille mellom hva som er somatisk helsehjelp, og hva som er psykisk helsehjelp.

\section{Vi trenger kunnskap om både sykepleie, juss og etikk}

En tredje grunn til at vi trenger etikken i tillegg til lovverket, er at det som er juridisk riktig, ikke alltid behøver å være moralsk godt eller riktig. Hvis vi følger lovverket og retningslinjer slavisk uten å bruke skjønn, kan vi risikere å krenke pasienter eller pårørende.

\section{«Hvis vi følger lovverket og retningslinjer slavisk uten å bruke skjønn, kan vi risikere å krenke pasienter eller pårørende.»}

«I møte med konkrete situasjoner hender det at intensjonene om det beste ikke blir oppfylt om lovens formulering eller bokstav følges», skriver Alvsvåg og Martinsen (7). Formålet med etikken er nettopp å ivareta verdigheten og på den måten unngå at pasienter eller pårørende blir krenket (8). 
Så kan vi også spørre hva som kommer først av etikken og jussen. Her tror jeg at det igjen er situasjonen, skjønnet og samvittigheten til den enkelte som må avgjøre. Det krever imidlertid at vi har den nødvendige kunnskapen og kompetansen, både innen sykepleie, juss og etikk. Bare da vil vi kunne utøve et godt moralsk skjønn.

\section{Referanser}

1. Løgstrup KE, Fink H. Den etiske fordring. 4. utg. Århus: Klim; 2010.

2. Ohnstad B. Juss i sjukepleie. Oslo: Samlaget; 2021.

3. Heggestad AKT. Etikk i klinisk sjukepleie. Oslo: Samlaget; 2018.

4. Tønnessen S, Scott A, Nortvedt P. Safe and competent nursing care: an argument for a minimum standard? Nurs Ethics. 2020;27(6):1396-407. DOI: $\underline{10.1177 / 0969733020919137}$

5. Lov 2. juli $1999 \mathrm{nr} .63$ om pasient- og brukerrettigheter (pasient- og brukerrettighetsloven). Tilgjengelig fra: https://lovdata.no/dokument/NL/lov/1999O7-02-63 (nedlastet 31.01.2022).

6. Hem MH, Gjerberg E, Pedersen R, Førde R. Pleie og omsorg i grenselandet mellom frivillighet og tvang. Sykepleien Forskning. 2010;5(4):294-301. DOI: $\underline{10.4220 / \text { sykepleienf.2011.0007 }}$

7. Alvsvåg H, Martinsen KM. Omsorg og skjønn. Tidsskrift for omsorgsforskning. 2018;4(O3):215-22. DOI: 10.18261/issn.2387-5984-2018-03-03

8. Heggestad AKT. Verdighet som fenomen i sykepleien. I: Knutstad U, Heggestad AKT, red. Sykepleieboken: 2. Sentrale begreper og fenomener i klinisk sykepleie. 4. utg. Oslo: Cappelen Damm Akademisk; 2016. s. 23-39. 